\title{
Teachers' Attitude towards E-Learning in Higher Education in Macedonia Case Study: University of Tetovo
}

\author{
Gazmend Xhaferi, Arta Farizi, and Rovena Bahiti
}

\begin{abstract}
Nowadays in higher education it is important integration of new information and communication technologies into the learning and teaching process. Fastest development of computer technologies and the Internet as a communication platform has motivated higher education institutions to start to think about integration of e-learning system on teaching and learning process on their university. Elearning is becoming progressively more important in higher education environment. Teacher is one of the most important stockholder for integration of e-learning. The purpose of this paper is to analyze the perception of teachers' attitudes towards e-learning. In this study were analyzed 49 teachers teaching in 2 major faculties in University of Tetovo, in Macedonia. The results show that a significant number of teachers agree about the plan to blend the present teaching method with e-learning, on the other hand, a great number of teachers not agree to replace traditional teaching method with e-learning. The results show that the number that prefer using traditional teaching method is the same with those that not agree. There is no any significant correlation between teacher' attitudes towards various e-learning according to gender and faculty. Results shows that teachers' attitudes have important role towards e-learning in teaching process. These results can be a good example for creation a platform or framework for the implementation of e-learning environment in the teaching and learning process on higher education. In addition, the results of the study can serve as an important factor for the improvement and development of the educational process supported by the use of technology, thus implementing an elearning system in order to help and facilitate the students in their studies.
\end{abstract}

Index Terms-Higher Education; E-Learning; Teachers' Attitude; Gender; Faculty.

\section{INTRODUCTION}

Information and Communication Technologies have made a huge change in the daily life of the people, their work and education in the 21st century. In the last decade one of the most significant developments in the use of information technologies in universities has been the integration of e-learning systems to support the processes of teaching and learning. E-Learning is a concept derived from the use of information and communication technologies (ICTs) to improve and transform traditional teaching and learning models and practices [1]. The integration and adopting e-learning has become widely accepted across higher education in many developed countries, including the

Published on July 26, 2018.

G. Xhaferi, and R. Bahiti are with the Department of Statistical and Applied Informatics at University of Tirana, Tirana, Albania (e-mail: gazmend.xhaferi@unite.edu.mk).

A. Farizi is with the Department of Computer Sciences - Software and Applications at South East European University, Tetovo, Macedonia.
USA, UK, most European countries and Australia [2],[3]. This change has had a significant impact on the curricula, the methodology of teaching, and learning processes. On the other hand, developing countries also appear to adopt elearning in their higher education to improve and enhance the learning and teaching process, but still faces a number of obstacles and challenges [4]. However, The Republic of Macedonia is a country in development in every aspect of life, as well as in education. Higher education in Macedonia is still in transition period of using methodology in teaching and learning process, so, in many universities still is used traditional methodology, face-to-face of teaching and learning. Although there have university in Macedonia that have begun implementation of a management system for elearning, but on the other hand UT has not yet implemented any learning management system in teaching and learning process.

Institutions of higher learning in developing countries have lagged behind those in the developed world in elearning adoption, mainly due to cost and poor Internet infrastructure. Introduction of e-learning system in such institutions is often complex involving integration of new technology, resistance by users (lecturers and students) [5]. Thus e-learning has become a very crucial part on the educational environment. This paper represents the teachers attitudes toward e-learning. To successfully integrate and implement educational technology in education program depends strongly on the teachers' attitudes. Therefore, the attitudes of lecturers towards technology greatly influence their adoption and integration of technology into their teaching and learning process. Positive attitude towards ICTs is widely recognized as a necessary condition for the effective implementation" [6]. The role of lecturer is to effectively utilize integrated e-learning systems as a platform on education environment.

\section{RESEARCH OBJECTIVES}

The goal of this research is to analyze teacher' attitude towards e-learning in University of Tetovo. The objectives of this research are as follow:

$\checkmark \quad$ To analyze perception of teachers toward e-learning in teaching process.

$\checkmark \quad$ To analyze the role of gender and faculty on perception of teachers toward e-learning.

\section{RESEARCH METHODOLOGY}

In this research is used a survey method to examine the perception of teachers towards e-learning. The target population consists of 49 university teachers. The total number of questionnaires distributed to teachers was 60 , 
comprising the following faculty such as Faculty of Natural Science and Mathematics and Faculty of Economics. Out of the 60 lecturers who received the questionnaire, 49 completed and returned the questionnaire given an eightytwo percent $(82 \%)$ rate of return. The actual sample size used in the study was sufficient to meet this target sample size.

The survey instrument consisted of two section. First section consists from demographic profile of teachers such as gender, age, faculty and teaching experience. The second section examined the perception of teachers towards elearning.

\section{DATA ANALYSIS AND RESUlTS}

Statistical Package for Social Science (SPSS) software was used to analyze data. The Study collected data from 49 teachers. Descriptive statistics (frequency and percentage distributions) were used to represents the demographic characteristics of the teachers (gender, faculty, teaching experience, age) which are presented in the Table I. The desired sample size was 60 but the actual number of teachers who fill questionnaire was 49 , yielding a high response rate of $82 \%$. Most of the teachers identified as male accounted a $30(61.2 \%), \%)$ whereas $19(38.8 \%)$ were females. In terms of faculty, results demonstrate that 35 $(71.4 \%)$ teachers belong to the Faculty of Natural Science and Mathematics and $14(28.6 \%)$ to the Faculty of Economics. Data on teaching experience revealed that there were $5(10.2 \%)$ teachers with teaching experience less than 6 years and $6(12.2 \%)$ teachers with teaching experience from 6 to 10 years. Furthermore, $13(26.6 \%)$ teachers had 11 to 15 years of teaching experience and the last category had $25(51 \%)$ teachers with more than 15 years of teaching experience. Teachers age range was normally distributed with four categories, first category is between age range of 23-30 years, $(11,22.45 \%)$; second category within age range of $31-40,(12,24.5 \%)$; third category between $41-50,(15$, $30.6 \%)$; and finally those over 50 years $(11,22.45 \%)$.

TABLE I: DEMOGRAPHIC STATISTICS

\begin{tabular}{c|c|c|c}
\hline \hline \multirow{2}{*}{$\begin{array}{c}\text { Demographic } \\
\text { Characteristics }\end{array}$} & Category & N. of teachers \& Percentage \\
& & $\mathrm{N}$ & $\%$ \\
\hline \multirow{2}{*}{ Gender } & Male & 30 & 61.2 \\
& Female & 19 & 38.8 \\
\hline \multirow{3}{*}{ Faculty } & Natural Science & 35 & 71.4 \\
& and Mathematics & & \\
& Economics & 14 & 28.6 \\
\hline \multirow{3}{*}{ Teaching } & $0-5$ years & 5 & 10.2 \\
Experience & 6 - 10 years & 6 & 12.2 \\
& $11-15$ years & 13 & 26.6 \\
& Over 15 years & 25 & 51.0 \\
\hline \multirow{2}{*}{ Age } & 23 - 30 years & 11 & 22.45 \\
& 31 - 40 years & 12 & 24.50 \\
& $41-50$ years & 15 & 30.60 \\
& Over 50 years & 11 & 22.45 \\
\hline \hline
\end{tabular}

In this section will be analyzed the perception of teachers towards e-learning with the help of multiple choice questions. As the first question ask teacher to response towards usage of ICT in teaching process. The results show in the Fig. 1.

From teachers' response of the first question, results show that $32.7 \%$ of teachers used ICT every day in their teaching process, only around $49 \%$ used often. This was followed by $8.20 \%$ teachers rarely. The rest $16.30 \%$ never using ICT in teaching process.

The next question focused on understanding the current usage of multimedia presentations tools by the teachers in the classroom

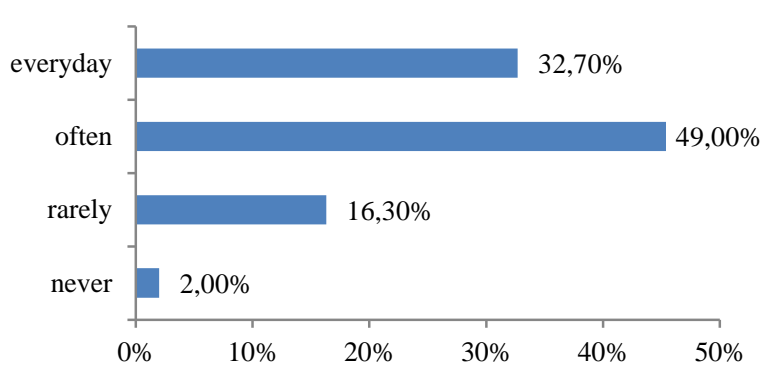

Fig.1. Teachers response towards use of ICT in class

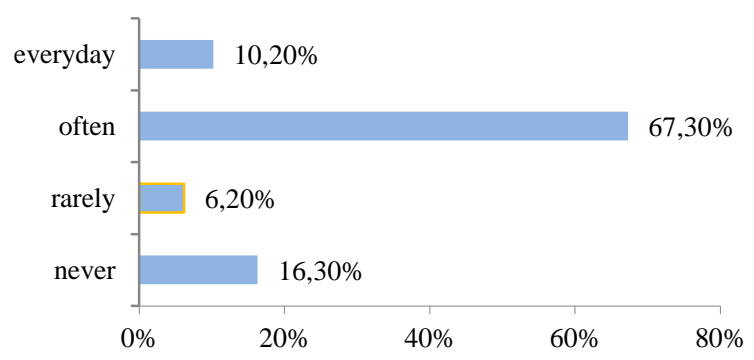

Fig. 2 Teachers response towards use of multimedia presentation in teaching process

This result indicated that majority of teachers i.e. around $67.30 \%$ use multimedia presentation in their teaching class that is a good idea and can be implemented for benefits of students as well as teachers. Results show that just $10.20 \%$ use every day, than $6.2 \%$ rarely and never $16.3 \%$ (Fig. 2).

The next question asks the teachers to respond about using web-based teaching method in their teaching process. The results indicate that $63.3 \%$ of teachers never used webbased teaching method in their teaching process, $12.2 \%$ rarely and $24.5 \%$ sometimes (Fig. 3).

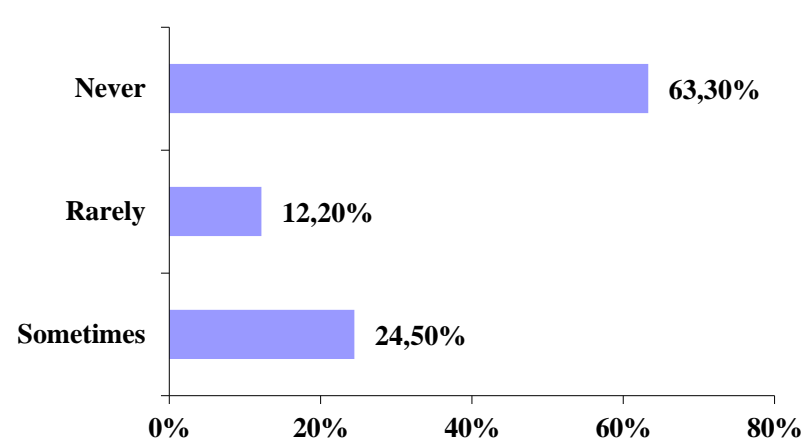

Fig. 3. Teachers response towards used web-based teaching method

Another question collected information that whether the teachers plans to blend the current teaching method with elearning. The results suggested that $57.10 \%$ teachers agree with blending current teaching method with e-learning. From the results shows that $38.80 \%$ were still undecided and only a small number that is $4.10 \%$ responded in negation (Fig. 4). 


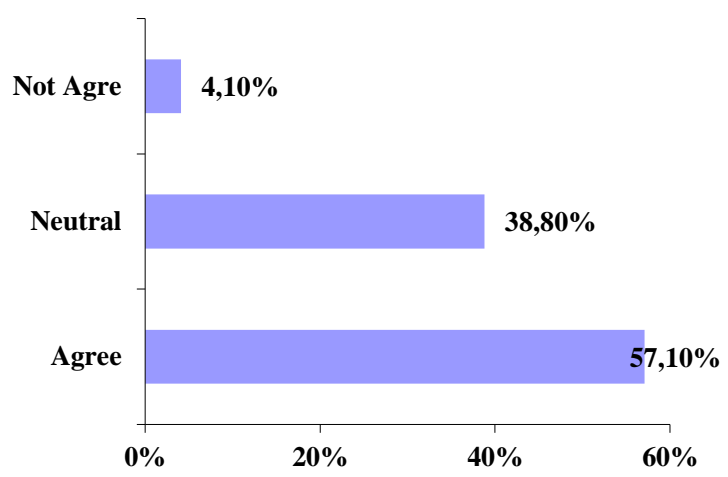

Fig. 4. Teachers towards plan to blend current teaching method with elearning

Another question that were asked teachers is to respond how much those prefer traditional (face-to-face) teaching method in class. The results show that $40.8 \%$ of teachers respond that Agree of using traditional method in teaching class, $18.4 \%$ were neutral and $40.8 \%$ not agree, (Fig.5). In the final question the teachers were asked whether the present learning methodology should be replaced with elearning. Results indicates that more than $53.10 \%$ teachers feel that full e-learning teaching method cannot replace the present learning methodology. From the results show that $26.5 \%$ were neutral and 20.4 response that e-learning can replace present learning methodology (Fig. 6).

In this study the second objective was to analyses the role of gender and faculty on perception of teachers toward elearning. In the Table II were represent the comparison between genders towards perception of various teaching method and in Table III according to faculty.

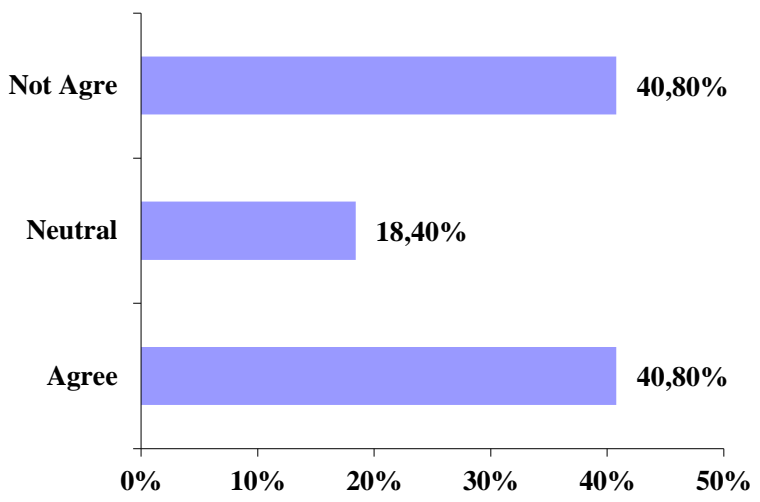

Fig. 5. Teachers prefer traditional teaching method in class.

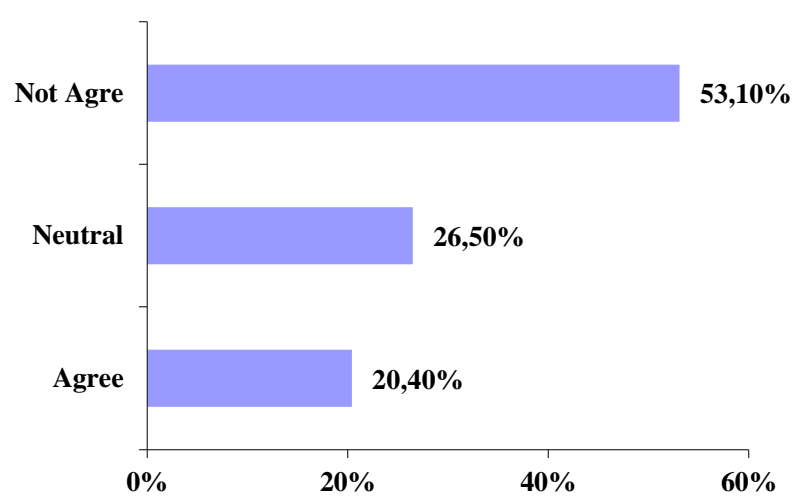

Fig. 6. Teachers' response that e-learning can replace present learning methodology.
TABLE II: TEACHERS' RESPONSE TOWARDS VARIOUS E-LEARNING QUESTIONS ACCORDING TO GENDER.

\begin{tabular}{c|c|c|c|c}
\hline \hline Questions & Gender & $\begin{array}{c}\text { Not } \\
\text { Agree }\end{array}$ & Neutral & Agree \\
\hline $\begin{array}{c}\text { Traditional method of } \\
\text { teaching }\end{array}$ & Male & 9 & 5 & 16 \\
\cline { 2 - 5 } & Female & 11 & 4 & 4 \\
\hline $\begin{array}{c}\text { Plan to blend present } \\
\text { teaching method with e- } \\
\text { learning }\end{array}$ & Male & 2 & 14 & 14 \\
\cline { 2 - 5 } $\begin{array}{c}\text { Transform present } \\
\text { teaching method with e- } \\
\text { learning }\end{array}$ & Female & 0 & 5 & 14 \\
\cline { 2 - 5 } & Female & 17 & 6 & 7 \\
\hline \hline
\end{tabular}

TABLE III: TEACHERS' RESPONSE TOWARDS VARIOUS E-LEARNING QUESTIONS ACCORDING TO FACULTY.

\begin{tabular}{l|c|c|c|c}
\hline \multicolumn{5}{c}{ QUESTIONS ACCORDING TO FACULTY. } \\
\hline \multirow{2}{*}{$\begin{array}{l}\text { Traditional method of } \\
\text { teaching }\end{array}$} & Faculty & Not Agree & Neutral & Agree \\
\cline { 2 - 5 } & FNSM $^{1}$ & 13 & 7 & 15 \\
\hline $\begin{array}{l}\text { Plan to blend present } \\
\text { teaching method with e- } \\
\text { learning }\end{array}$ & FNSM & 2 & 15 & 18 \\
\cline { 2 - 5 } & FE & 4 & 10 & 14 \\
\hline $\begin{array}{l}\text { Transform present } \\
\text { teaching method with e- } \\
\text { learning }\end{array}$ & FNSM & 20 & 8 & 7 \\
\cline { 2 - 5 } & FE & 6 & 5 & 3 \\
\hline \hline
\end{tabular}

From Table II and Table III, conclude that factor gender and also the faculty factor does not play any role in the responses of the teacher towards blend learning, traditional learning and e-learning. These results also correspond to the findings of others researchers [7],[8].

The Pearson correlation coefficients were used to measure the relationships between the variables. The aim of correlation analysis is to find is there exist association or correlation between two (or more) variables and to what degree. Results shows Table IV that no significant correlation between teachers' attitudes towards various teaching method based in gender. Also, the same results indicate that no significant correlation between teachers' attitudes towards various teaching method according to faculty (see Table V).

TABLE IV: CORRELATION BETWEEN TEACHER'S RESPONSES TOWARDS VARIOUS E-LEARNING QUESTIONS BASED ON GENDER

\begin{tabular}{c|c|c|c}
\hline \hline \multirow{2}{*}{ Gender } & $\begin{array}{c}\text { Prefer } \\
\text { traditional } \\
\text { teaching } \\
\text { method }\end{array}$ & $\begin{array}{c}\text { Blend present } \\
\text { learning with } \\
\text { e-learning }\end{array}$ & $\begin{array}{c}\text { Towards e- } \\
\text { learning in } \\
\text { teaching }\end{array}$ \\
\cline { 2 - 4 } Pearson Correlation & -.325 & .280 & .057 \\
Sig. (2-tailed) & .023 & .052 & .699 \\
$\mathrm{~N}$ & 49 & 49 & 49 \\
\hline \hline
\end{tabular}

TABLE V: CORRELATION BETWEEN TEACHER'S RESPONSES TOWARDS VARIOUS E-LEARNING QUESTIONS BASED ON FACULTY

\begin{tabular}{c|c|c|c}
\hline \multirow{2}{*}{ Faculty } & $\begin{array}{c}\text { Prefer } \\
\text { traditional } \\
\text { teaching } \\
\text { method }\end{array}$ & $\begin{array}{c}\text { Blend present } \\
\text { learning } \\
\text { with e- } \\
\text { learning }\end{array}$ & $\begin{array}{c}\text { Towards e- } \\
\text { learning in } \\
\text { teaching }\end{array}$ \\
\cline { 2 - 4 } Pearson Correlation & -.100 & .202 & .114 \\
Sig. (2-tailed) & .494 & .164 & .433 \\
$\mathrm{~N}$ & 49 & 49 & 49 \\
\hline \hline
\end{tabular}

${ }^{1}$ FNSM-Faculty of Natural Science and Mathematics

${ }^{1}$ FE- Faculty of Economics 


\section{CONCLUSION}

The fastest development of Information and Communication Technology and also integration of elearning systems in education field have become essentials to educational processes. Many higher educational institutions in Republic of Macedonia have adopted some learning management system. Those systems increase the quality of learning, encourage students and teachers to be more interactive, and removing the limitations of time and space in learning and teaching process. The purpose of this research was to analyze the perception of teachers' attitudes towards e-learning. Results indicate that teachers often use ICT in their teaching process. Also, results show that $67.30 \%$ of teachers often use multimedia presentation. On the other hand, most of the teachers' response that never used web-based teaching method in teaching and learning process. the results show that teachers of University of Tetovo in the great number overall $57 \%$ are towards blend the present traditional teaching method (face-to-face) with elearning. On the other hand, results show that is the same percentage $(40.80 \%)$ among teachers have a preference using just traditional teaching method with those that not agree. Finally, results show that more than $50 \%$ teachers' response that e-learning cannot replace the present learning methodology in teaching process. Also, has be done the analysis of correlation between variables gender and faculty with teachers' attitudes towards various teaching method. Results show that there is no significant correlation between teacher' attitudes towards various e-learning according to gender and faculty. So, gender and faculty does not have any impact on perception of teachers' attitudes towards traditional teaching method, plan to blend present teaching with e-learning and also towards e-learning. These results can serve as an example for UT and others university in region to follow the strategies with integration of ICT and elearning in higher education for teaching and learning processes and to achieve teaching and learning goals like others Universities in developed countries.

\section{REFERENCES}

[1] Muheisin, Ibrahim (2010), "The role of e-learning systems in addressing the problems of education in Arabic (official website of Prof. Dr. Ibrahim Al-Muhaisen".

[2] Paredes, Joaquín, \& Correa, J-M. (2010). E-learning plataforms use and teaching and learning models in the European Higher Education Area. Paper presented at the International Conference on Financial Theory and Engineering (ICFTE), 2010.

[3] Saowapakpongchai, Kultida. (2010). The development of elearning model for higher education in Thailand. International Conference on Educational and Network Technology (ICENT).

[4] Khashkhush, Abdulbasit Salem. (2011). Analysis of factors affecting the implementation of elearning in higher education (HE) in Libya University of Salford.

[5] Collis, B. A., \& Moonen, J. (2005). An on-going journey: Technology as a learning workbench. Public address, University of Twente, Enschede, The Netherlands.

[6] Sife, A., Lëoga, E. \& Sanga, C. (2007). Neë technologies for teaching and learning: Challenges for higher learning

[7] Bakr Samira M. (2011). "Attitudes of Egyptian Teachers towards Computers", Volume: 2, Issue: 4, October - 2011 Pages: 308 - 318

[8] Zaid, Bassfar, Rozinah Jamaludin, and Merza Abas (2012). "Investigate the Self-efficacy and Attitudes of Teachers towards elearning in Saudi Arabia", International Journal of Scientific \& Engineering Research, Volume 3, Issue 6.

Mr Gazmend Xhaferi is a PhD candidate in the department of Statistical and Applied Informatics at University of Tirana in Tirana, Albania, where he is currently undertaking a research project entitled "Integration and impact of a system for organizing e-learning in the higher education. Case study: University of Tetovo". He is Assistant at Faculty of Natyral Sciences and Mathematics at University of Tetovo, in Tetovo, Republic of Macedonia. He has published a series of articles on conferences and journals on the field of of e-larning.

Mrs. Arta Farizi is a Mrsc. candidate in the department of Computer Sciences - Software and Applications at South East European University in Tetovo, Macedonia. She is teacher primary schole "Perparimi" in Tetovo, Republic of Macedonia.

Prof. Asoc. Dr. Rovena Bahiti is Associate Professor in the department of Statistical and Applied Informatics at University of Tirana in Tirana, Albania. She has more than 20 papers. She has been involved in numerous research and evaluation projects in the field of education and Financial and Accounting Financial. She has been for several years consultative at World Bank and other donor projects in the role of expert in financial management of projects. In December 2013 she was appointed Director of the National Computer Security Agency (ALCIRT), holding it until April 2017. 